\title{
Dieta proteinowa w świetle zasad racjonalnego żywienia. Analiza składu jadłospisów
}

\section{Protein-based diet with respect to the principles of rational nutrition. Menus analysis}

\author{
Małgorzata Szczuko $\bowtie$, Natalia Pieszak, Dominika Jamioł-Milc, Ewa Stachowska \\ Pomorski Uniwersytet Medyczny w Szczecinie, Zakład Biochemii i Żywienia Człowieka, ul. Broniewskiego 24, 71-460 Szczecin \\ $\bowtie$ malgorzata.szczuko@pum.edu.pl
}

\begin{abstract}
Introduction: A diet high in protein and low in carbohydrates has four phases, first of them being the attack phase, which eliminates carbohydrates to the highest extent. In subsequent phases the consumption of carbohydrates is gradually allowed but their ratio is limited.

The aim of performed studies was to analyze the metabolic effects of protein-based diet. The hypothesis - the analysis based on the composition of the diets should draw the attention to health risks being not only related to too high consumption of protein.

Materials and methods: In the study, 40 diets were composed according to the objectives of high protein diet - 10 diets for each of the four phases. Next, the diets were introduced into dietetic program Dietician 2 recommended by the National Food and Nutrition Institute in Poland, and the amounts of nutrients supplied with the diets were calculated. Those amounts were compared to the currently recommended dietary allowances in Poland. Results: Based on too high consumption of some nutrients and the deficiency of others in the diets, the highest detrimental effect was determined for the first two phases of the diet. In all four
\end{abstract}

phases of the diet, too high consumption of protein, UFA and cholesterol was determined, which amounted to $148.8-160.5 \mathrm{~g} /$ day, $12.5-16.2 \mathrm{~g} /$ day and $467.7-488.7 \mathrm{mg} /$ day, respectively. Simultaneously, too low average consumption was noted in case of energy (1131-1690 kcal), carbohydrates (58.2-149.4 g) and dietary fiber (3.3-28.7 g) in all phases of the diet. Additionally, the deficiency in vitamin E (2.69-7.21 mg) was observed in the first three phases of the diet, and thiamin in the first two phases (0.72-1.02 mg). The most deficient phase of the diet was the first phase - the attack phase, where the deficiency also concerned folacin (154.4 mg/day), vitamin C (6.14 mg), potassium (2947.7 mg), iron (7.19 mg), copper (0.59 mg) and magnesium (294.8 mg). Conclusions: The main causes of body mass reduction in high protein diet are caloric restrictions in all diet phases. The analyses of diets compositions determined the potential negative effect of using this diet in case of people with predisposition to kidney diseases, gout, cardiovascular diseases, anemia and erythropoiesis disorders. The most detrimental was the first phase of the diet, which entirely eliminates carbohydrate products. Keywords: protein-based diet; protein intake; trendy diets; diet health risk.

\begin{abstract}
ABSTRAKT
Wstęp: Dieta wysokobiałkowa i zarazem ubogowęglowodanowa składa się z czterech faz. Najbardziej eliminująca węglowodany jest faza I, uderzeniowa. W kolejnych fazach stopniowo dopuszcza się spożycie węglowodanów, jednak ich udział jest bardzo ograniczony.

Celem przeprowadzonych badań była analiza efektów metabolicznych, jakie wywiera dieta proteinowa. Na podstawie analizy opartej na składzie jadłospisów zwrócono uwagę na zagrożenia niebędące tylko wynikiem zbyt wysokiego spożycia białka. Materiały i metody: Przeanalizowano 40 jadłospisów ułożonych zgodnie z założeniami diety wysokobiałkowej. Przygotowano po 10 jadłospisów do każdej z faz. Następnie jadłospisy wprowadzono do programu dietetycznego Dietetyk 2 rekomendowanego przez Instytut Żywności i Żywienia oraz wyliczono ilości dostarczonych składników pokarmowych, które porównano do aktualnie obowiązujących norm żywienia w Polsce.

Wyniki: Na podstawie uzyskanych danych, świadczących o zbyt wysokim spożyciu niektórych składników pokarmowych przy równoczesnym niedoborze innych, wykazano najwyższą szkodliwość pierwszych dwóch faz diety wysokobiałkowej. We wszystkich czterech fazach diety stwierdzono zbyt wysokie średnie
\end{abstract}

spożycie białka, nasyconych kwasów tłuszczowych i cholesterolu, które wynosiło odpowiednio 148,8-160,5 g/d, 12,5-16,2 g/d, 467,7-488,7 mg/d. Jednocześnie odnotowano zbyt niskie średnie spożycie energii (1131-1690 kcal), węglowodanów (58,2-149,4 g) i błonnika (3,3-28,7 g) we wszystkich fazach diety. Dodatkowo niedobór witaminy E (2,69-7,21 mg) zaobserwowano w pierwszych trzech fazach diety, a tiaminy $(0,72-1,02 \mathrm{mg})$ w pierwszych dwóch. Najbardziej niedoborową fazą diety była faza I, uderzeniowa, w której niedobory dotyczyły także folianów $(154,4 \mathrm{mg} / \mathrm{d})$, witaminy C (6,14 mg), potasu (2947,7 mg), żelaza (7,19 mg), miedzi $(0,59 \mathrm{mg})$ i magnezu $(294,8 \mathrm{mg})$.

Wnioski: Głównym powodem redukcji masy ciała w diecie wysokobiałkowej są restrykcje kaloryczne we wszystkich fazach diety. W badaniu składu jadłospisów wykazano możliwość negatywnego wpływu stosowania diety u osób z predyspozycjami do chorób nerek, dny moczanowej, chorób układu krążenia, niedokrwistości i zaburzeń erytropoezy. Najbardziej niebezpieczna okazała się faza I diety, która eliminuje całkowicie produkty węglowodanowe z jadłospisu.

Słowa kluczowe: dieta proteinowa; podaż białka; modne diety; zagrożenia zdrowotne diety. 


\section{WSTĘP}

Omawiana dieta redukcyjna o wysokiej zawartości białka i jednocześnie niskiej podaży węglowodanów składa się z czterech faz: uderzeniowej (ataku), naprzemiennej, utrwalania i stabilizacji. Faza I, eliminująca węglowodany, jest krótka i ma za zadanie intensywnie pobudzić metabolizm (białko, odpowiednie przyprawy jak chili). Ważne w tej fazie jest wypijanie odpowiedniej ilości wody $(1,5-2$ L). Faza naprzemienna może trwać nawet kilka miesięcy, w zależności od liczby kilogramów, które chce się zredukować. Przez 5 dni stosowane są jadłospisy z fazy I, a przez kolejne 5 jadłospisy wzbogacone w warzywa, z wyjątkiem pokarmów zawierających skrobię (ziemniaki, rośliny suche strączkowe, ryż, kukurydza, karczochy, buraki). Długość fazy III wynosi 10 dni na każdy utracony kilogram. W fazie tej dopuszcza się spożycie pieczywa razowego, ziemniaków i ryżu 2-krotnie w ciągu tygodnia oraz owoców o niskim indeksie glikemicznym. W fazie IV panuje już pewna dowolność w doborze produktów, jednak przez 1 dzień w tygodniu należy stosować jadłospis z fazy ataku.

Wydaje się, że autor, opracowując założenia diety białkowej, pragnął stworzyć taki plan żywieniowy, który nie wyniszczy organizmu, nie doprowadzi do niedoboru witamin i składników mineralnych, przy czym bez większego reżimu żywieniowego będzie przynosił satysfakcjonujące efekty redukcji masy ciała. W okresie, kiedy dieta proteinowa biła rekordy popularności w Polsce, książka pt. „Nie potrafię schudnąć” została sprzedana w ponad 100 tys. egzemplarzach, a wielu ludzi cieszyło się utratą znacznej liczby kilogramów [1]. Na okładce wydania angielskiego książki zauważyć można również slogan: „5 milionów Francuzów nie może się mylić". Trudno więc jest dyskutować o braku skuteczności diety, szczególnie z osobami, którym pozwoliła osiągnąć szczuplejszą sylwetkę. Jednak zagrożeń zdrowotnych, jakie niesie ze sobą stosowanie diety wysokobiałkowej, jest wiele, nawet jeśli w jadłospisach uwzględni się produkty o obniżonej zawartości tłuszczu i wyeliminuje produkty tłuste.

Celem przeprowadzonych badań była ocena wartości odżywczej diety proteinowej na przykładzie składu ilościowego jadłospisów ułożonych zgodnie z założeniami jej autora. Kolejnym celem było określenie zagrożeń zdrowotnych wynikających z długoterminowego stosowania poszczególnych faz diety wysokobiałkowej.

\section{MATERIAtY I METODY}

Na potrzeby badań opracowano 40 jadłospisów zgodnie z zasadami diety wysokobiałkowej. Z uwagi na to, iż dieta ta składa się z czterech różnych faz, na każdą z nich przypadło po 10 jadłospisów. Jadłospisy uwzględniały dziennie 5 posiłków, których podstawą były produkty i potrawy użyte w fazie I. Asortyment ten był stopniowo rozszerzany w kolejnych fazach zgodnie z zasadami diety. Badacze w doborze produktów posiłkowali się gotowymi recepturami zawartymi w książkach pt. „Nie potrafię schudnąć” oraz „Metoda doktora Dukana”. Brano pod uwagę produkty o obniżonej zawartości tłuszczu w zwyczajowych gramaturach ich spożycia (chude sery twarogowe i jogurty naturalne, mleko 0,5\%, tuńczyk w sosie własnym, drób bez skóry) oraz warzywa zielone i żółte jako główne źródła folianów. W jadłospisach uwzględniono gramaturę każdego produktu. Po skompletowaniu wszystkich 40 jadłospisów, każdy z nich wprowadzono do programu dietetycznego Dietetyk 2 rekomendowanego przez Instytut Żywności i Żywienia w Warszawie. Następnie wyliczono podaż energii oraz składników pokarmowych z uwzględnieniem strat kulinarnych w każdym $\mathrm{z}$ jadłospisów.

Na podstawie uzyskanych wyników obliczono średnią spożycia składników pokarmowych i odchylenie standardowe odpowiednio dla każdej z faz. Wyniki średniego spożycia z 10 dni porównano z obecnie obowiązującymi normami żywienia, przyjmując wartości referencyjne dla witamin i składników mineralnych przedstawionych w tabeli 1, dla energii w tabeli 2, dla składników odżywczych w tabeli 3. W przypadku występowania zakresu wartości referencyjnych, wartości te uśredniono (wapń, sód).

Wykonano również obliczenia statystyczne. Średnia arytmetyczna (x), odchylenie standardowe (SD) oraz różnice statystycznie istotne (test Tuckeya przy $\mathrm{p} \leq 0,05$ ) zostały wyliczone z użyciem programu Statistica 9.0 (Statsoft).

\section{WYNIKI}

W tabeli 2 przedstawiono średnią dzienną podaż energii w poszczególnych fazach, która wynosiła 1131,4-1680,5 kcal.

TABELA 1. Wartości referencyjne spożycia witamin i składników mineralnych [2]

\begin{tabular}{|c|c|c|c|c|}
\hline \multirow{2}{*}{ Składnik } & \multicolumn{2}{|c|}{ Kobiety } & \multicolumn{2}{|c|}{ Mężczyźni } \\
\hline & RDA & Al & RDA & Al \\
\hline$A(\mu g)$ & 700 & & 900 & \\
\hline$E(m g)$ & - & 8 & - & 10 \\
\hline $\mathrm{D}(\mu \mathrm{g})$ & - & 11 & - & 9 \\
\hline $\mathrm{C}(\mathrm{mg})$ & 75 & - & 90 & - \\
\hline Tiamina (mg) & 1,1 & - & 1,3 & - \\
\hline Ryboflawina (mg) & 1,1 & - & 1,3 & - \\
\hline Niacyna (mg) & 14 & - & 16 & - \\
\hline Pirydoksyna (mg) & 1,5 & - & 1,4 & - \\
\hline Foliany $(\mu g)$ & 400 & - & 400 & - \\
\hline Kobalamina $(\mu g)$ & 2,4 & - & 2,4 & - \\
\hline Wapń (g) & - & 1150 & - & 1150 \\
\hline Fosfor (mg) & 700 & - & 700 & - \\
\hline Magnez (mg) & - & 320 & 420 & - \\
\hline Żelazo (mg) & 18 & - & 10 & - \\
\hline Cynk (mg) & 8 & - & 11 & - \\
\hline Miedź (mg) & 0,9 & - & 0,9 & - \\
\hline Potas (mg) & - & 4700 & - & 4700 \\
\hline Sód (g) & - & 1425 & - & 1425 \\
\hline
\end{tabular}


TABELA 2. Średnia podaż energii w jadłospisach w poszczególnych fazach diety z uwzględnieniem płci i aktywności fizycznej

\begin{tabular}{lccccc}
\multicolumn{1}{c}{ Parametry } & Faza I & Faza II & Faza III & Faza IV & Zakres normy \\
\hline Podaż energii & $1131,4 \mathrm{kcal}$ & $1256,4 \mathrm{kcal}$ & $1560,0 \mathrm{kcal}$ & $1680,5 \mathrm{kcal}$ & - \\
\hline Realizacja normy - mężczyźni, mała aktywność fizyczna & $39,8-52,9 \%$ & $44,2-58,8 \%$ & $54,9-73,0 \%$ & $59,1-78,6 \%$ & $1800-3330 \mathrm{kcal}$ \\
\hline Realizacja normy - mężczyźni, umiarkowana aktywność fizyczna & $36,3-48,2 \%$ & $40,03-53,5 \%$ & $50,1-66,5 \%$ & $54,0-71,6 \%$ & $1900-3600 \mathrm{kcal}$ \\
\hline Realizacji normy - kobiety, mała aktywność fizyczna & $47,8-60,6 \%$ & $53,1-67,2 \%$ & $65,9-83,5 \%$ & $71,01-89,9 \%$ & $1700-2700 \mathrm{kcal}$ \\
\hline Realizacji normy - kobiety, umiarkowana aktywność fizyczna & $43,2-56,0 \%$ & $48-62,2 \%$ & $59,6-77,2 \%$ & $64,2-83,1 \%$ & $1900-3000 \mathrm{kcal}$ \\
\hline
\end{tabular}

TABELA 3. Średnia zawartość składników odżywczych w jadłospisach oraz odsetek realizacji normy (\%) z uwzględnieniem fazy diety, płci i aktywności fizycznej

\begin{tabular}{|c|c|c|c|c|}
\hline \multicolumn{2}{|l|}{ Parametry } & \multirow{2}{*}{$\frac{\text { Białko (g) }}{37-66}$} & \multirow{2}{*}{$\begin{array}{c}\text { Ttuszcze (g) } \\
49-110\end{array}$} & \multirow{2}{*}{ Węglowodany (g) } \\
\hline \multirow{2}{*}{ Wartości referencyjne dla mężczyzn } & mate AF/EAR & & & \\
\hline & umiarkowane AF/RDA & $45-81$ & $53-120$ & \multirow{3}{*}{$100-130$} \\
\hline \multirow{2}{*}{ Wartości referencyjne dla kobiet } & mate AF/EAR & $33-58$ & $46-90$ & \\
\hline & umiarkowane AF/RDA & $41-72$ & $51-98$ & \\
\hline Faza I-podaż & & 148,8 & 32,7 & 58,2 \\
\hline \multirow{2}{*}{ Faza I - mężczyźni, য19\% realizacji normy } & mała AF & \multirow{2}{*}{$183,7-330,6$} & $29,7-66,7$ & \multirow{2}{*}{44,8} \\
\hline & umiarkowana AF & & $27,3-61,7$ & \\
\hline \multirow{2}{*}{ Faza I - kobiety, $\geq 19 \%$ realizacji normy } & mata AF & \multirow{2}{*}{$206,6-362,9$} & $36,3-71,1$ & \multirow{2}{*}{44,8} \\
\hline & umiarkowana $\mathrm{AF}$ & & $33,4-64,1$ & \\
\hline Faza II - podaż & & 153,1 & 36,1 & 85,7 \\
\hline \multirow{2}{*}{ Faza II - mężczyźni, z19\% realizacji normy } & mała AF & \multirow{2}{*}{$189,8-340,2$} & $32,8-73,6$ & \multirow{2}{*}{66,8} \\
\hline & umiarkowana AF & & $30,1-68,1$ & \\
\hline \multirow{2}{*}{ Faza II - kobiety, $\geq 19 \%$ realizacji normy } & mała AF & \multirow{2}{*}{$212,6-376,4$} & $40,1-78,4$ & \multirow{2}{*}{66,8} \\
\hline & umiarkowana $\mathrm{AF}$ & & $36,8-70,7$ & \\
\hline Faza III - podaż & & 156,9 & 38,2 & 170,5 \\
\hline \multirow{2}{*}{ Faza III - mężczyźni, য19\% realizacji normy } & mała AF & \multirow{2}{*}{$193,7-348,7$} & $34,8-78,1$ & \multirow{2}{*}{131,2} \\
\hline & umiarkowana AF & & $31,9-72,2$ & \\
\hline \multirow{2}{*}{ Faza III - kobiety, $\geq 19 \%$ realizacji normy } & mała AF & \multirow{2}{*}{$218,0-382,8$} & $42,5-83,2$ & \multirow{2}{*}{131,2} \\
\hline & umiarkowana AF & & $39,0-75,0$ & \\
\hline Faza IV - podaż & & 160,5 & 46,0 & 194,2 \\
\hline \multirow{2}{*}{ Faza IV - mężczyźni, $\geq 19 \%$ realizacji normy } & mała AF & \multirow{2}{*}{$198,8-356,8$} & $41,8-93,9$ & \multirow{2}{*}{149,4} \\
\hline & umiarkowana $\mathrm{AF}$ & & $38,4-86,8$ & \\
\hline Faza IV - kobiety, $\geq 19 \%$ realizacji normy & mata AF & $223,0-391,6$ & $51,1-100,1$ & 149,4 \\
\hline
\end{tabular}

AF - aktywność fizyczna; EAR - średnie zapotrzebowanie dla grupy; RDA - poziom zalecanego spożycia

Podaż energii była zatem mniejsza niż zapotrzebowanie energetyczne osób o umiarkowanej aktywności fizycznej i mężczyzn o małej aktywności fizycznej. Porównując normy spożycia dla mężczyzn i kobiet o umiarkowanej aktywności fizycznej z uzyskanymi wynikami z analizy jadłospisów, stwierdzono $\mathrm{w}$ fazie I i II diety obniżenie o ponad 50\% całkowitego zapotrzebowania energetycznego, które wynosiło 36,3-48,6\%. Podobna zależność wystąpiła w grupie mężczyzn i kobiet o małej aktywności fizycznej.

Z danych zestawionych w tabeli 3 wynika, iż dzienna podaż białka w każdej z faz była znacznie przekroczona i wynosiła 148,8-160,5 g. Odsetek realizacji normy na białko w każdej z faz był zbyt wysoki i wynosił w grupie mężczyzn 189,9-356,8, a w grupie kobiet 206,6-391,6.

Zawartość tłuszczu w dietach była obniżona w pierwszych trzech fazach diety zarówno w grupie kobiet, jak i mężczyzn. Odsetek realizacji normy wynosił odpowiednio 33,4-83,2 i 27,3-78,1. W fazie IV podaż tłuszczu nadal była obniżona, jednak dla osób o mniejszym zapotrzebowaniu osiągała wartości prawidłowe. Należy zaznaczyć, że podaż tłuszczu w żadnej z faz nie przekraczała wartości referencyjnych.

Ograniczenie spożycia węglowodanów w diecie spowodowało ich niedobór w każdej z faz diety, przy czym w fazie I i II realizacja normy nie pokrywała nawet zapotrzebowania komórek mózgowych na glukozę i wynosiła 44,8-66,8\% realizacji normy. Jeżeli chodzi o cholesterol, jego nadmiar obecny był w każdej fazie diety (tab. 4). Ilość spożywanego cholesterolu była wyższa o ponad 50\% od wartości dopuszczalnej dla osób zdrowych i wynosiła średnio 467,7-488,7 mg/d. W przypadku osób, u których występują choroby układu krążenia, zaleca się, aby spożycie cholesterolu nie przekraczało $200 \mathrm{mg} / \mathrm{d}$; a zatem norma została przekroczona ponad 2-krotnie.

Rozpatrując podaż błonnika, można zaobserwować wyraźną rozbieżność pomiędzy dwoma pierwszymi fazami diety oraz dwoma ostatnimi. W fazie I błonnik prawie nie występuje, w fazie II spożycie wynosi ok. $15 \mathrm{~g} / \mathrm{d}$. W kolejnych fazach osiąga wartości zbliżone do prawidłowych, wynoszące 26-28,7 g/d. Pomimo niskiej podaży energii w pierwszych dwóch fazach 
TABELA 4. Odsetek realizacji normy na cholesterol, błonnik i nasycone kwasy tłuszczowe oraz ich średnia zawartość w diecie

\begin{tabular}{lcccc}
\multirow{2}{*}{ Składnik } & \multicolumn{4}{c}{ Realizacja normy } \\
\cline { 2 - 5 } & faza I & faza II & faza III & faza IV \\
\hline \multirow{2}{*}{ Cholesterol } & $467,7 \mathrm{mg}$ & $488,7 \mathrm{mg}$ & $488,1 \mathrm{mg}$ & $470,7 \mathrm{mg}$ \\
& $(155,9 \%)$ & $(162,9 \%)$ & $(162,7 \%)$ & $(156,9 \%)$ \\
\hline \multirow{2}{*}{ Błonnik } & $3,3 \mathrm{~g}$ & $14,8 \mathrm{~g}$ & $26,0 \mathrm{~g}$ & $28,7 \mathrm{~g}$ \\
& $(13,0 \%)$ & $(59,2 \%)$ & $(103,9 \%)$ & $(114,9 \%)$ \\
\hline Kwasy tłuszczowe & $12,5 \mathrm{~g}$ & $13,6 \mathrm{~g}$ & $14,5 \mathrm{~g}$ & $16,2 \mathrm{~g}$ \\
nasycone & $(32,2 \%)$ & $(37,6 \%)$ & $(37,9 \%)$ & $(35,2 \%)$ \\
\hline
\end{tabular}

diety, spożycie nasyconych kwasów tłuszczowych jest bardzo wysokie i wynosi odpowiednio 12,5 oraz 13,6 g/d. W każdej z faz odsetek realizacji normy z nasyconych kwasów tłuszczowych wynosi ponad 30, mieszcząc się w zakresie 32,2-37,9.

W fazie I stwierdzono największy niedobór witamin. Zawartość witaminy E i tiaminy wynosiła odpowiednio 26,9\% i 55,4\% w grupie mężczyzn oraz 33,6\% i 65,5\% w grupie kobiet (tab. 5). Obu witamin za mało było również w fazie II, a witaminy E także w fazie III w grupie mężczyzn. Charakterystyczne niskie wartości spożycia witamin w fazie I wiązały się także z niskim spożyciem witaminy A (52,2\% i 67,1\%), folianów (38,6\%) i witaminy C $(6,8 \%$ i $8,2 \%)$. Pozostałe witaminy były spożywane w ilościach, które nie powinny wywoływać objawów ich niedoboru.

Podobnie jak w przypadku witamin, podaż składników mineralnych była niewystarczająca tylko w fazie I (tab. 6). Sytuacja ta dotyczyła spożycia potasu i miedzi na poziomie realizacji odsetka normy wynoszącej odpowiednio 62,7 i 65,6 w obu grupach. Dodatkowo wystąpił niedobór żelaza u kobiet wynoszący 44,1\% i mężczyzn 28,1\% oraz niedobór magnezu w grupie mężczyzn $(71,1 \%)$.
Struktura energii w każdej z faz była bardzo niekorzystna. Najwyższy odsetek energii uzyskano z białka i wynosił on od 55,2 w fazie I do $36 \mathrm{w}$ fazie IV. Chociaż zawartość węglowodanów wzrasta wraz z kolejną fazą diety, w żadnej nie osiągnięto wartości energii z węglowodanów zbliżonej do prawidłowego zakresu 55-65\%. Najkorzystniej rozkładał się odsetek energii z tłuszczu ogółem, który mieścił się w zakresie 21,9-25 (ryc. 1).

\section{DYSKUSJA}

Badania Amerykańskiego Towarzystwa Nauk Żywieniowych z 2003 r. przeprowadzone przez Laymana i wsp. wykazały skuteczność stosowania diety wysokobiałkowej w utracie masy ciała podczas odchudzania dorosłych kobiet. Po 10 tyg. stosowania diety uzyskano redukcję masy ciała średnio o 7,53 kg, przy czym redukcja tkanki tłuszczowej wynosiła 5,60 kg [3]. Efekt ten uzyskano nie tylko wskutek redukcji tkanki tłuszczowej, ale również odwodnienia. Skov i wsp. wykazali, że grupa osób stosujących dietę bogatą w białko zwierzęce osiągnęła bardziej zadowalające efekty redukcji masy ciała niż grupa na diecie redukcyjnej z optymalną zawartością białka [4]. Jednak proporcja zredukowanej tkanki tłuszczowej do redukcji masy ciała ogółem była korzystniejsza w diecie o optymalnej zawartości białka. Wielu autorów zwraca uwagę, że dotychczasowe badania prowadzone były przez krótki czas, natomiast brak jest danych dotyczących skuteczności utraty masy ciała oraz bezpieczeństwa stosowania diety przez dłuższy czas $[5,6,7]$.

\begin{tabular}{|c|c|c|c|c|c|c|c|c|c|}
\hline \multirow{2}{*}{\multicolumn{2}{|c|}{ Składnik }} & \multicolumn{4}{|c|}{ Mężczyźni 19.-75. r.ż. } & \multicolumn{4}{|c|}{ Kobiety 19.-75. r.ż. } \\
\hline & & faza I & faza II & faza III & faza IV & faza I & faza II & faza III & faza IV \\
\hline \multirow{2}{*}{ Wit. A } & podaż $(\mu \mathrm{g})$ & 469,9 & 1255,1 & 1210,8 & 1382,3 & 469,9 & 1255,1 & 1210,8 & 1382,3 \\
\hline & \% normy & 52,2 & 139,5 & 134,5 & 153,6 & 67,1 & 179,3 & 173,0 & 197,5 \\
\hline \multirow{2}{*}{ Wit. D } & podaż $(\mu \mathrm{g})$ & 11,69 & 12,64 & 11,13 & 10,07 & 11,69 & 12,64 & 11,13 & 10,07 \\
\hline & $\%$ normy & 165,6 & 179,1 & 157,7 & 142,7 & 126,6 & 136,9 & 120,6 & 109,1 \\
\hline \multirow{2}{*}{ Wit. E } & podaż $(\mathrm{mg})$ & 2,69 & 6,81 & 7,21 & 9,06 & 2,69 & 6,81 & 7,21 & 9,06 \\
\hline & $\%$ normy & 26,9 & 68,1 & 72,1 & 90,6 & 33,6 & 85,1 & 90,1 & 113,3 \\
\hline \multirow{2}{*}{ Wit. $B_{1}$} & podaż (mg) & 0,72 & 1,02 & 1,31 & 1,29 & 0,72 & 1,02 & 1,31 & 1,29 \\
\hline & \% normy & 55,4 & 78,5 & 100,8 & 99,2 & 65,5 & 92,7 & 119,1 & 117,3 \\
\hline \multirow{2}{*}{ Wit. $B_{2}$} & podaż (mg) & 3,38 & 3,78 & 3,54 & 3,37 & 3,38 & 3,78 & 3,54 & 3,37 \\
\hline & \% normy & 260 & 290,8 & 272,3 & 259,2 & 307,3 & 343,6 & 321,8 & 306,4 \\
\hline \multirow{2}{*}{ Niacyna } & podaż (mg) & 26,99 & 30,32 & 32,01 & 29,56 & 26,99 & 30,32 & 32,01 & 29,56 \\
\hline & $\%$ normy & 168,7 & 189,5 & 200,1 & 184,8 & 192,8 & 216,6 & 228,6 & 211,1 \\
\hline \multirow{2}{*}{ Wit. $B_{6}$} & podaż (mg) & 2,19 & 3,09 & 3,25 & 3,33 & 2,19 & 3,09 & 3,25 & 3,33 \\
\hline & \% normy & 148,6 & 209,7 & 220,6 & 226 & 157,2 & 221,8 & 233,3 & 239,1 \\
\hline \multirow{2}{*}{ Foliany } & podaż $(\mu \mathrm{g})$ & 154,4 & 362,6 & 377,5 & 376,0 & 154,4 & 362,6 & 377,5 & 376,0 \\
\hline & $\%$ normy & 38,6 & 90,6 & 94,4 & 94 & 38,6 & 90,6 & 94,4 & 94 \\
\hline \multirow{2}{*}{ Wit. $B_{12}$} & podaż $(\mu \mathrm{g})$ & 11,61 & 12,03 & 10,90 & 10,05 & 11,61 & 12,03 & 10,90 & 10,05 \\
\hline & $\%$ normy & 483,8 & 501,3 & 454,2 & 418,8 & 483,8 & 501,3 & 454,2 & 418,8 \\
\hline \multirow{2}{*}{ Wit. C } & podaż (mg) & 6,14 & 119,67 & 131,81 & 154,85 & 6,14 & 119,67 & 131,81 & 154,85 \\
\hline & $\%$ normy & 6,8 & 133 & 146,5 & 172,1 & 8,2 & 159,6 & 175,7 & 206,5 \\
\hline
\end{tabular}


TABELA 6. Średnia zawartość w jadłospisach i odsetek realizacji normy na składniki mineralne z uwzględnieniem płci

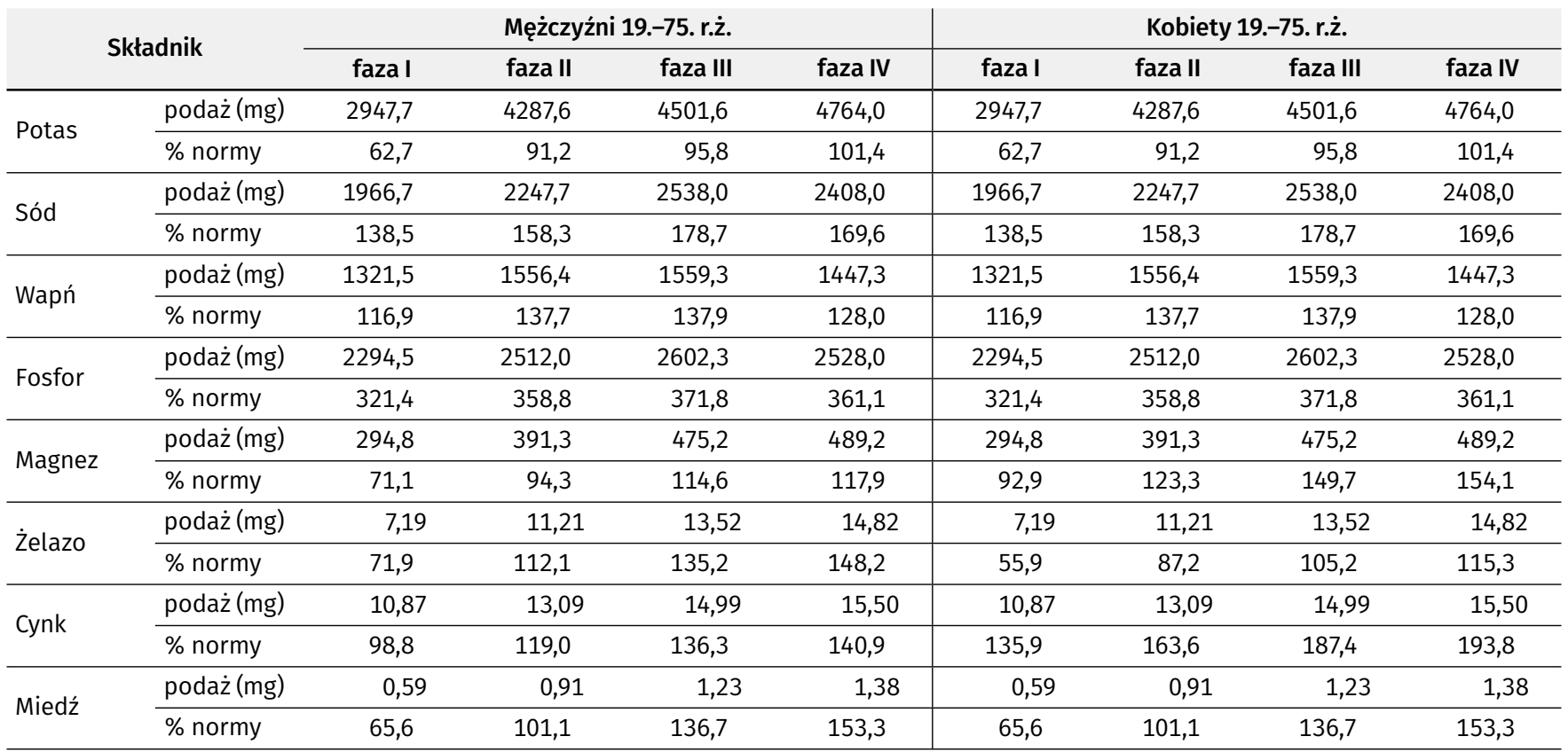

Faza I

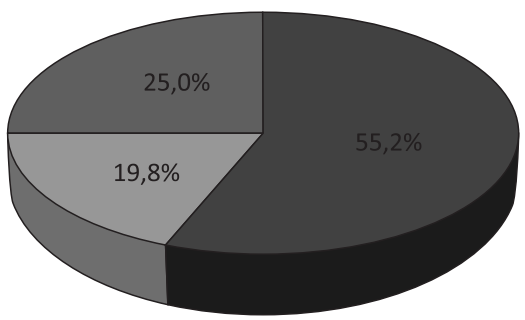

Faza III

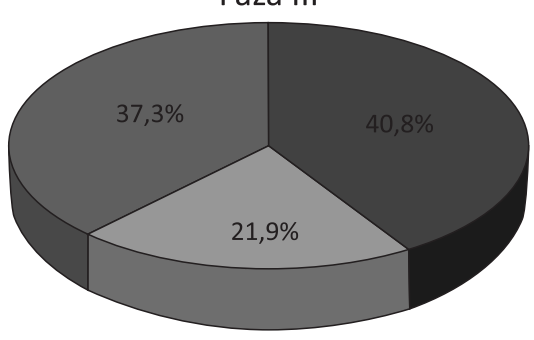

energia z białka

energia z tłuszczu

energia z węglowodanów

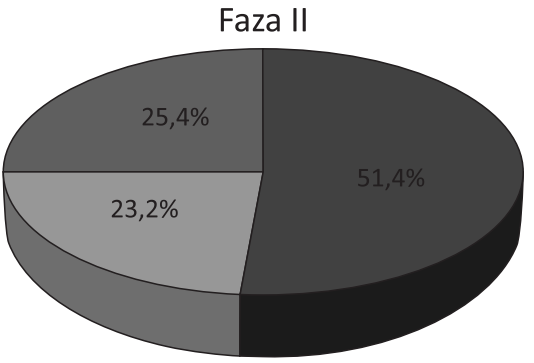

Faza IV

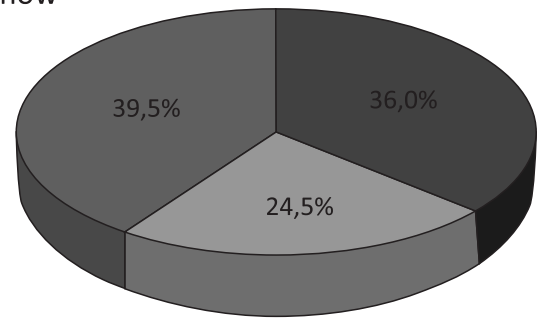

RYCINA 1. Struktura energii w poszczególnych fazach diety

Dieta bogata w białko i zarazem uboga w węglowodany zaprzecza zasadom racjonalnego żywienia, zgodnie z którymi 10-15\% energii powinna pochodzić z białka, a 50-65\% z węglowodanów [1]. Do wypracowania omawianej metody żywienia przesłanką mogły być informacje dotyczące wpływu zwiększonej zawartości węglowodanów (szczególnie oczyszczonych) w diecie na metabolizm, poprzez zwiększenie stężenia glukozy oraz triglicerydów w surowicy [8]. Dieta bogata w białka pochodzenia zwierzęcego dostarcza tłuszczów nasyconych i cholesterolu, co wpływa na podniesienie poziomu lipoprotein o niskiej gęstości oraz cholesterolu ogółem w osoczu [5]. Zastosowanie diety wysokobiałkowej bez ograniczenia produktów wysokotłuszczowych niesie dodatkowo zagrożenie w postaci niekorzystnych zmian profilu lipidowego. Norma spożycia nasyconych kwasów tłuszczowych wynosi poniżej $10 \%$ energii. Wyniki badań niniejszej pracy wskazują, że poziom ten został przekroczony w każdej z faz, mieszcząc się w zakresie 32,16-37,86\% diety redukcyjnej. Chociaż odsetek ten został przekroczony, to przy doborze produktów o niższej zawartości tłuszczu w diecie można go uznać za prawidłowy. Podaż cholesterolu w diecie także przewyższyła normę o ok. $170 \mathrm{mg} / \mathrm{d}$, co w dłuższym okresie przyczyni się do rozwoju aterogennej dyslipidemii i wystąpienia lub rozwoju chorób sercowo-naczyniowych. Białka występujące w takich produktach jak mięso, drób, owoce morza i jaja są bogate w puryny, których pochodną jest kwas moczowy. Nadmierne spożycie wymienionych produktów, które należą do bazowych w diecie wysokobiałkowej, zwiększa stężenie kwasu moczowego w krwiobiegu 
i sprzyja zwiększeniu ciśnienia kłębuszkowego oraz hiperfiltracji w nerkach, co może być zagrożeniem dla osób z nieprawidłową funkcją nerek [5, 9]. Wyniki badań prowadzonych w 2003 r. wykazały, że wysokie spożycie białka jest potencjalnym czynnikiem ryzyka dla postępującej utraty pozostałych czynności nerek u pacjentów dializowanych [10]. U pacjentów podaż białka zwiększa się na poziomie 1,1-1,2 g/kg m.c., nie jest to jednak dieta wysokobiałkowa. Natomiast ograniczenie białka w diecie do 0,6-0,8 g/ kg m.c./d zostało uznane za jeden ze sposobów leczenia pacjentów z chorobami nerek [11]. Chociaż zwiększone spożycie białka ma negatywny wpływ zdrowotny na osoby z ostrą i przewlekłą chorobą nerek, wskutek zmniejszenia szybkości przesączania kłębuszkowego, w piśmiennictwie trudno znaleźć wyniki badań, które wykazywałyby związek pomiędzy spożyciem białka a wystąpieniem problemu niewydolności nerek u zdrowych osób [12]. Natomiast nadmierna konsumpcja białka, mimo mechanizmów adaptacyjnych, zwiększa wydzielanie substancji potencjalnie litologicznych, jak kwas moczowy i wapń, przez co może przyczyniać się do powstawania kamieni u osób zdrowych. Wydaje się, że długotrwałe obciążenie jakiegokolwiek narządu powoduje jego nadmierne indywidualne przeciążenie i utratę możliwości pracy, co sugerują Juraschek i wsp. [13]. Należy zwrócić uwagę na to, że spożycie białka przez niektóre osoby stosujące dietę może być znacznie wyższe niż 2,5 g/kg m.c. i nieść ze sobą jeszcze większe ryzyko uszkodzenia nerek [14].

W praktyce zawodowej dietetyka autorzy pracy spotykali pacjentów stosujących własne modyfikacje diety wysokobiałkowej, spożywających ponad 15 jaj tygodniowo (wraz z żółtkami) i wzbogacających swoje posiłki dodatkowo w odżywki białkowe dla sportowców, którzy skarżyli się na wiele dolegliwości ustrojowych. Rozpatrując skład przedstawionej diety pod względem zawartości błonnika pokarmowego, stwierdzić można jego duży deficyt w fazie I i II. W kolejnych fazach podaż była zbliżona do prawidłowej pod warunkiem uwzględnienia w diecie otrąb, o których pacjenci często zapominają. Badania prowadzone na Uniwersytecie w Aberdeen w Szkocji nad stosowaniem diety wysokobiałkowej i ubogowęglowodanowej jednocześnie ujawniły wiele następstw metabolicznych, które budzą obawy o prawidłowe funkcjonowanie jelit, jeśli dieta byłaby stosowana przez dłuższy czas [15]. Autorzy tych badań zauważyli, że wraz z niską ilością dostarczonych węglowodanów i zmniejszeniem spożycia włókna pokarmowego zmniejsza się spożycie związków fenolowych, zwłaszcza kwasu ferulowego. Substancje te uważane są za predyktory ochrony przed nowotworem jelita grubego (wskutek zwiększenia perystaltyki jelit, wiązania substancji szkodliwych i stymulowania rozwoju właściwej dla organizmu flory bakteryjnej). Dodatkowo stwierdzono zmianę pH kału, mikrobioty jelit i wzrost stężenia szkodliwych metabolitów, co stwarza ryzyko chorób okrężnicy i odbytnicy [16, 17].

Nowotwór jelita grubego jest najczęstszą postacią spośród nowotworów żołądkowo-jelitowych, stanowiąc istotną część globalnej zachorowalności na nowotwory [18]. Jak podają Parkin i wsp. [19], nowotwór jelita grubego stanowi ok. 8\% wszystkich zgonów związanych z nowotworami na świecie. Russel i wsp. zauważyli, że w tego typu diecie należy zwiększyć ilość błonnika pokarmowego w celu usprawnienia perystaltyki jelit [15]; wniosek ten koresponduje z danymi epidemiologicznymi World Cancer Research Found z 2007 r. [20]. Wydaje się, że spożycie błonnika jedynie w postaci otrąb w ostatnich fazach opisanej diety może być niewystarczające. Chociaż białko pochodzące ze źródeł zwierzęcych jest istotne dla prawidłowej gęstości kości, to jego wysokie spożycie zostało uznane również za czynnik ryzyka wystąpienia osteoporozy i złamań kości ze względu na pobudzenie wydalania wapnia z moczem poprzez zmianę pH krwi [21]. W badaniach innych autorów porównujących dietę z niską zawartością białka oraz dietę wysokobiałkową również wykazano zwiększone wydalanie wapnia z moczem $[22,23]$. Jednak wielu autorów badań wykazało jednocześnie, że długotrwałe zwiększone spożycie białka korzystnie wpływa na gęstość mineralną kości $[23,24]$ i nie powoduje utraty masy kostnej przyczyniającej się do wystąpienia osteoporozy $[25,26]$. Dane na ten temat są sprzeczne, czego przyczyną może być fakt, iż nie wzięto pod uwagę aktywności fizycznej badanych.

Dieta wysokoproteinowa jest uboga, szczególnie w fazie I, w wiele niezbędnych dla właściwego funkcjonowania ustroju składników mineralnych, jak potas, magnez, miedź czy żelazo. Niedobór żelaza jest szczególnie zauważalny w dietach, w których uwzględniono wysoką podaż nabiału i drobiu, a w mniejszym stopniu czerwonego mięsa. W tym wymiarze wraz z niedoborem witaminy $\mathrm{C}$ będzie wpływać na osłabienie funkcji leukocytów [27] oraz wystąpienie niedokrwistości. W dietach zauważono także niedobór witamin $\mathrm{A}, \mathrm{E}, \mathrm{B}_{1}$ i folianów, mimo że autor zapewnia, iż suplementacja w diecie nie jest konieczna. Analiza składu jadłospisów wykazała niedobory składników pokarmowych, a w związku z tym potrzebę wprowadzenia suplementacji.

Opierając się na badaniach jadłospisów ułożonych zgodnie z zaleceniami diety wysokobiałkowej, można stwierdzić, że jej powodzenie w redukcji masy ciała warunkowane jest przede wszystkim przez obniżoną podaż energii. Ilość dostarczanej energii dla wielu osób może być niewystarczająca, ponieważ podaż poniżej podstawowej przemiany materii jest szkodliwa dla zdrowia. Ta zależność jest szczególnie istotna dla dobrostanu psychicznego i biologicznego funkcjonowania organizmu, wpływając na wzrost produkcji hormonu stresu kortyzolu [28]. Wzrost stężenia kortyzolu powoduje rozpad białek, a uwolnione aminokwasy (głównie alanina i glutamina) są wykorzystywane w procesie glukoneogenezy. Już w 1994 r. udokumentowano występowanie u osób pozostających na restrykcyjnych dietach zwiększoną nerwowość, rozdrażnienie, obniżenie poczucia własnej wartości, lęku i depresji [29]. Długotrwały stres i związane z nim obciążenia allostatyczne negatywnie wpływają na układ sercowo-naczyniowy, prowadząc do udaru i zawału mięśnia sercowego [30]. Dodatkowo zwiększenie wydatkowania energii w procesach trawienia białka może być równoważone przez zmniejszenie perystaltyki jelit wskutek niedoboru błonnika $\mathrm{w}$ diecie. 
Dieta ta jest mało urozmaicona, nie zaspokaja potrzeb organizmu na niektóre witaminy i składniki mineralne, a co najistotniejsze, ma zaburzone proporcje udziału składników odżywczych w bilansie energetycznym. Jej długotrwałe stosowanie może być przyczyną wypracowania nieprawidłowych nawyków żywieniowych i pogłębiać istniejące już nieprawidłowości, sprzyjając jednocześnie wypracowaniu schematu postępowania charakterystycznego dla osób z zaburzeniami odżywiania.

\section{WNIOSKI}

1. Planowane zgodnie z założeniami diety białkowej jadłospisy nie zaspokajały potrzeb energetycznych dla kobiet i mężczyzn w żadnej z czterech faz diety, co było głównym powodem redukcji masy ciała. Najbardziej niebezpieczna okazała się faza I diety, która eliminuje całkowicie produkty węglowodanowe $\mathrm{z}$ jadłospisu.

2. Każda $\mathrm{z}$ faz diety stwarza ryzyko rozwoju chorób układu krążenia z uwagi na wysokie spożycie cholesterolu i możliwe wysokie spożycie nasyconych kwasów tłuszczowych oraz niskie spożycia folianów regulujących stężenie homocysteiny. Zatem dieta wysokobiałkowa nie powinna być stosowana przez osoby, u których stwierdzono miażdżycę.

3. Długoterminowe stosowanie diety wysokobiałkowej może wpływać na wypracowanie irracjonalnych nawyków żywienia i pogłębić istniejące nieprawidłowości w sposobie żywienia.

Z powodu deficytu i nadmiaru niektórych składników pokarmowych w diecie proteinowej przychodzą na myśl także dodatkowe implikacje:

1) wysoka podaż białka stwarza ryzyko nadmiernego obciążenia nerek i wystąpienia ich dysfunkcji. Dieta wysokobiałkowa nie powinna być stosowana przez osoby, u których występują jakiekolwiek dysfunkcje tego narządu;

2) zbyt wysokie spożycie białka w diecie bez zwiększenia aktywności fizycznej niezbędnej dla wzrostu masy mięśniowej może wpływać na zmniejszenie gęstości kości przez obniżenie pH i przyczyniać się do rozwoju osteoporozy;

3) Przy wyeliminowaniu z diety czerwonego mięsa pojawia się dodatkowo niskie spożycie żelaza, co przy równoczesnym niedoborze folianów, cynku i miedzi może być przyczyną obniżenia poziomu hemoglobiny oraz ilości prawidłowo zbudowanych erytrocytów. Dieta proteinowa stwarza niebezpieczeństwo dla prawidłowego przebiegu erytropoezy i dlatego może być zagrożeniem zdrowotnym dla osób z niedokrwistością.

\section{PIŚMIENNICTWO}

1. Dukan P. Nie potrafię schudnąć. 350 nowych przepisów. Kraków: Wyd. Otwarte; 2009.

2. Jarosz M, editor. Normy żywienia dla populacji - nowelizacja. Instytut Żywności i Żywienia. Warszawa: Instytut Żywienia i Żywności; 2012.

3. Layman DK, Boileau RA, Erickson DJ, Painter JE, Shiue H, Sather C, et al. A reduced ratio of dietary carbohydrate to protein improves body com- position and blood lipid profiles during weight loss in adult women. J Nutr 2003;133(2):411-7.

4. Skov AR, Toubro S, Rønn B, Holm L, Astrup A. Randomized trial on protein vs carbohydrate in ad libitum fat reduced diet for the treatment of obesity. Int J Obes Relat Metab Disord 1999;23(5):528-36.

5. Sachiko T, Howard BV, Prewitt TE, Bovee V, Bazzarre T, Eckel RH. Dietary protein and weight reduction: a statement for healthcare professionals from the Nutrition Committee of the Council on Nutrition, Physical Activity, and Metabolism of the American Heart Association. Circulation 2001;104(15):1869-74.

6. Clifton PM, Keogh JB, Noakes M. Long-term effects of a high-protein weight-loss diet. Am J Clin Nutr 2008;87(1):23-9.

7. Lepe M, Bacardi Gascon M, Jimenez Cruz A. Long-term efficacy of high-protein diets: a systematic review. Nutr Hos 2011;26(6):1256-59.

8. Friedrich M, Kuchlewska M. Ocena wpływu wybranej mieszaniny dodatków do żywności na wskaźniki przemian węglowodanowo-lipidowych. Żywn Nauka Technol Jakość 2012;4(83):195-210.

9. Kim H, Lee S, Choue R. Metabolic responses to high protein diet in Korean elite bodybuilders with high-intensity resistance exercise. J Int Soc Sports Nutr 2011;8:10.

10. Johnson DW, Mudge DW, Sturtevant JM, Hawley CM, Campbell SB, Isbel NM, et al. Predictors of decline of residual renal function in new peritoneal dialysis patients. Perit Dial Int 2003;23(3):276-83.

11. Meloni C, Tatangelo P, Cipriani S, Rossi V, Suraci C, Tozzo C, et al. Adequate protein dietary restriction in diabetic and nondiabetic patients with chronic renal failure. J Ren Nutr 2004;14(4):208-13.

12. Martin WF, Armstrong LE, Rodriguez NR. Dietary protein intake and renal function. Nutr Metab 2005;2:25. doi: 10.1186/1743-7075-2-25.

13. Juraschek SP, Appel LJ, Anderson CA, Miller ER. Effect of a high-protein diet on kidney function in healthy adults: results from the OmniHeart trial. Am J Kidney Dis 2013;61(4):547-54.

14. Bączkowicz M, Fortuna T, Ogonek J. Jakość odżywek białkowo-węglowodanowych i preferencje konsumenckie osób o zwiększonej aktywności fizycznej. Żywn Nauka Technol Jakość 2007 6(55):268-76.

15. Russell WR, Gratz SW, Duncan SH, Holtrop G, Ince J, Scobbie L, et al. High-protein, reduced-carbohydrate weight-loss diets promote metabolite profiles likely to be detrimental to colonic health. Am J Clin Nutr 2011;93(5):1062-72.

16. Gingras D, Beliveau R. Colorectal cancer prevention through dietary and lifestyle modifications. Cancer Microenviron 2011;4(2):133-9.

17. Egeberg R, Olsen A, Loft S, Christensen J, Johnsen NF, Overvad K, et al. Intake of wholegrain products and risk of colorectal cancers in the Diet, Cancer and Health cohort study. Br J Cancer 2010;103(5):730-4.

18. Aryaie M, Roshandel G, Semnani S, Asadi-Lari M, Aarabi M, Vakili MA, et al. Predictors of colorectal cancer survival in Golestan, Iran: A Population-based Study. Epidemiol Health 2013;35. doi: 10.4178/epih/e2013004.

19. Parkin DM, Bray F, Ferlay J, Pisani P. Global cancer statistics, 2002. CA Cancer J Clin 2005;55(2):74-108.

20. World Cancer Research Found, American Institute of Cancer Research. Food nutrition, physical activity and the prevention of cancer: a global perspective. Washington: AICR, 2007.

21. Cao JJ, Johnson LK, Hunt JR. A diet high in meat protein and potential renal acid load increases fractional calcium absorption and urinary calcium excretion without affecting markers of bone resorption or formation in postmenopausal women. J Nutr 2011;141(3):391-7.

22. Kerstetter JE, O’Brien KO, Caseria DM, Wall DE, Insogna KL. The impact of dietary protein on calcium absorption and kinetic measures of bone turnover in women. J Clin Endocrinol Metab 2005;90(1):26-31.

23. Heaney RP. Effects of protein on the calcium economy. In: Burckhardt $P$, Heaney RP, Dawson-Hughes B, editors. Nutritional aspects of osteoporosis. Amsterdam: Elsevier Inc; 2007. p 191-7.

24. Darling AL, Millward DJ, Torgerson DJ, Hewitt CE, Lanham-New SA. Dietary protein and bone health: a systematic review and meta-analysis. Am J Clin Nutr 2009;90(6):1674-92.

25. Fenton TR, Eliasziw M, Lyon AW, Tough SC, Hanley DA. Meta-analysis of the quantity of calcium excretion associated with the net acid excretion of the modern diet under the acid-ash diet hypothesis. Am J Clin Nutr 2008;88(4):1159-66.

26. Fenton TR, Lyon AW, Eliasziw M, Tough SC, Hanley DA. Meta-analysis of the effect of the acid-ash hypothesis of osteoporosis on calcium balance. J Bone Miner Res 2009;24(11):1835-40. 
27. Aspuru K, Villa C, Bermejo F, Herrero P, López SG. Optimal management of iron deficiency anemia due to poor dietary intake. Int J Gen Med 2011;4:741-50.

28. Tomiyama AJ, Mann T, Vinas D, Hunger JM, Dejager J, Taylor SE. Low calorie dieting increases cortisol. Psychosom Med 2010;72(4):357-64.
29. French SA, Jeffery RW. Consequences of dieting to lose weight: effects on physical and mental health. Health Psychol 1994;13(3):195-212.

30. McEwen BS. Central effects of stress hormones in health and disease: Understanding the protective and damaging effects of stress and stress mediators. Eur J Pharmacol 2008;583(2-3):174-85. doi: 10.1016/j.ejphar.2007.11.071. 